\title{
Effect of pollen traps on the relapse of chronic bee paralysis virus in honeybee (Apis mellifera) colonies
}

\author{
Eric Dubois, Caroline Reis, Frank Schurr, Nicolas Cougoule, Magali Ribière-Chabert \\ Unit of Honey Bee Pathology, European Union Reference Laboratory for Honey Bee Health, ANSES - French Agency \\ for Food, Environmental and Occupational Health \& Safety, 105 route des Chappes, CS 20111, 06902, Sophia Antipolis, \\ France
}

Received 25 April 2017 - Revised 31 August 2017 - Accepted 21 September 2017

\begin{abstract}
Pollen traps are used by beekeepers to collect pollen harvested by honeybees. Here, we set up an experiment to evaluate whether pollen traps are a risk factor involved in the development of the chronic bee paralysis, a viral honeybee disease affecting adult bees and transmitted by contact. After a recent episode of chronic bee paralysis in an apiary, pollen traps were installed on three hives while two hives without pollen traps were used as control. During the experiment, the chronic bee paralysis virus (CBPV) loads in foragers from the control hives remained lower than $10^{8}$ equivalent copies of CBPV genome per bee but were higher than $10^{10}$ equivalent copies of CBPV genome per bee in the many symptomatic bees and in the hundreds of dead bees found in front of trap hives. Clinical signs of the disease persisted for 3 weeks at the entrance of the trap hives. These signs disappeared after the pollen traps were removed, accompanied by a decrease in the viral loads in foragers. Despite the small number of colonies examined, the results of this study suggest the impact of pollen traps on the relapse of chronic paralysis outbreaks in colonies infected by CBPV.
\end{abstract}

colony losses / weakening / honey bee foragers / viral disease

\section{INTRODUCTION}

The causes of honeybee colony losses and weakening remain unclear, certainly due to complex processes involving various stressors (Potts et al. 2010). These stressors, which can be pathogens (viruses, bacteria, parasites, and fungi), pesticides, inadequate nutrition due to monocropping, or poor colony management, are thought to contribute to mortality and weakening of honeybee colonies. Understanding how the various stressors interact can provide tools for improving honeybee colony health (Chauzat et al. 2016).

The chronic bee paralysis virus (CBPV) was isolated in 1963 (Bailey et al. 1963) and is

Corresponding author: E. Dubois, eric.dubois@anses.fr Manuscript editor: Stan Schneider recognized as one of the honeybee viruses affecting the health of honeybee colonies around the world (Allen and Ball 1996; Blanchard et al. 2009). CBPV is the etiological agent of chronic bee paralysis, affecting adult honeybees. The clinical signs include trembling bees, bees crawling on the ground, bees rejected at the hive entrance by the guards, bees with bloated abdomens, and hairless bees becoming dark and shiny (Ribière et al. 2010). Outbreaks of severe disease (leading to massive losses of foragers) are sporadic, but appear more frequently in spring and summer during the peak of colony (Ribière et al. 2010). High mortalities of hundreds of bees in front of the hive and the observation of trembling bees can be confused with the signs of intoxication. This risk of confusion underlines the need to perform discriminating diagnoses and to better understand the conditions that favor the onset of this disease. Like other honeybee viruses, CBPV generally persists as a covert infection in honeybee colonies 
(De Miranda et al. 2013) and factors favoring the chronic paralysis disease have not been completely identified. This disease is known to be favored by confinement of honeybees inside hives, increasing the contact between sick bees and healthy bees (Ball and Bailey 1997). In experimental studies, the virus is also transmitted by contact with infected feces (Ribière et al. 2007). Furthermore, experimental infection is enhanced via virus contact directly with the shaved cuticle of honeybees (Ribière et al. 2010). Therefore, natural or artificial alteration of cuticle integrity appears to be a factor potentially influencing honeybee health.

During the last decade, human consumption of and demand for pollen has been increasing, because consumers consider it to be a natural health product (Denisow and Denisow-Pietrzyk 2016). To collect pollen, beekeepers install pollen traps that force foragers laden with pollen to go through a screen at the hive entrance. The screen scrapes some of the pollen pellets from the corbicula and the pellets fall in a collecting tray under the hive entrance. For bees, pollen is required to satisfy the dietary requirements of developing larvae and young adult bees including protein (amino acids), fats/lipids, vitamins, minerals, and sterols (Di Pasquale et al. 2013; Scofield and Mattila, 2015). High efficiency pollen traps may reduce brood rearing after prolonged use. Prolonged use of pollen traps is also suspected to encourage the onset of chronic paralysis outbreak (ITSAP 2014).

In the present study, we tested the hypothesis of an interaction between pollen traps and CBPV by surveying the clinical signs and viral load in honeybees (Apis mellifera) from naturally CBPVinfected colonies fitted with pollen traps.

\section{MATERIAL AND METHODS}

\subsection{Experimental design}

In April 2014, cases of chronic bee paralysis were detected in the ANSES apiary at Sophia Antipolis, located in southeastern France. One month later, five hives were selected for the study. Pollen traps (Percie du Sert model, Icko, France) were installed on three hives (trap hives) and two hives without traps were chosen as control hives.
A plastic tarp was placed on the ground in front of the hives to collect the dead bees (Figure 1). Within each treatment group, the hives were separated from each other by a distance of $2 \mathrm{~m}$. About $10 \mathrm{~m}$ separated both groups to reduce the drifting of foragers between both groups. After 23 days, the pollen traps were removed from the three trap hives for an additional 19 days of observation. Clinical signs were recorded and samples were collected at the beginning of the study, 15 days later, and every week until the end of the study. Mortality between two visits (day 0, 15, 23, 29, 35 , and 42) was evaluated by estimating the number of dead bees on the plastic tarp. Three levels were used to describe mortality: level 1, less than 10 dead bees; level 2, up to 10 and less than 100 dead bees; and level 3, up to 100 dead bees.

\subsection{Sample processing}

The dead bees found in front of the hives, the bees resting on the flight board, emerging bees, and sealed brood were sampled and transferred to the laboratory within $1 \mathrm{~h}$. The samples were placed in sterile flasks and stored at $-78^{\circ} \mathrm{C}$ until processing. Ten bees (or larvae) from each sample were pooled and crushed as previously described (Blanchard et al. 2007). RNA purification, cDNA synthesis, and real-time PCR were carried out for the quantification of CBPV RNA as previously described by (Blanchard et al. 2012). The viral load in honeybees (or larvae) was expressed in equivalent copies of CBPV genome per individual (CBPV/individual) taking into account the number of bees (or larvae) tested and the recovery rate at each step of the process. According to previous validation trials (Blanchard et al. 2012), the limit of quantification (LOQ) of the method (RT-qPCR) is $10^{3.9} \mathrm{CBPV} /$ bee $\left(3.9 \log _{10}\right.$; considering a maximum uncertainty of $\left.0.5 \log _{10} \mathrm{CBPV} / \mathrm{bee}\right)$.

\subsection{Statistical analyses}

The viral loads ( $\log _{10}$-transformed values) between samples collected in both treatments were compared using a non-parametric test (MannWhitney $U$ test). Statistical analyses were performed using R software (Version 1.0.143 - (C) 

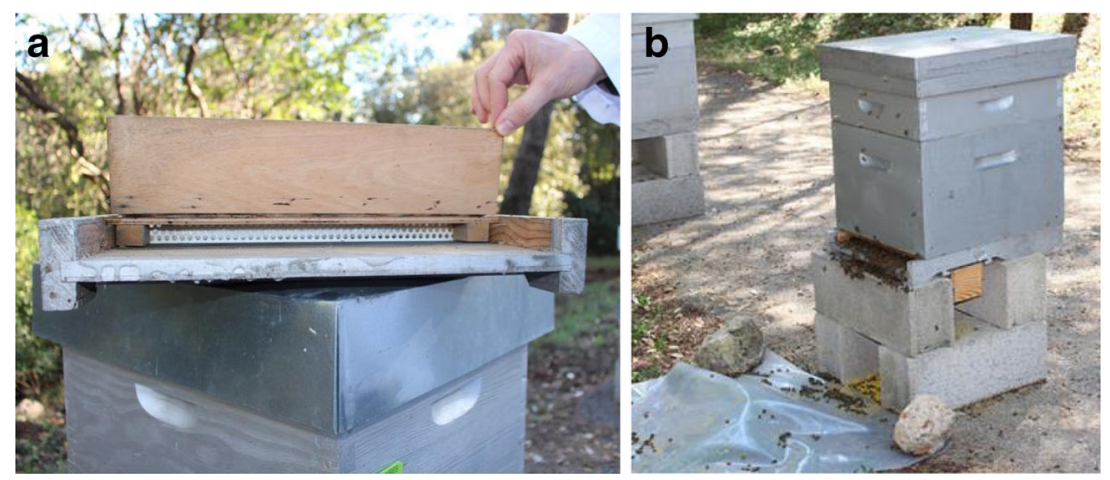

Figure 1. Hive with pollen traps. a Detail of the pollen trap used in the study (Percie du Sert model). b Hive 17 set with a pollen trap for 15 days. The photo shows the flight board occupied by foragers and dead bees on the plastic tarp.

2009-2016 RStudio). Differences were considered significant at $P<0.05$.

\section{RESULTS}

\subsection{Clinical signs in bees from experimental colonies}

The clinical signs observed in the three trap colonies and the two control colonies are described in Table I. Neither group showed any clinical signs of chronic bee paralysis at the beginning of the study. Only a few dead bees were found on the ground in front of the hives. Fifteen days after installing the pollen traps, the flight boards of the trap hives were occupied by hundreds of foragers. Trembling bees, dark bees, and crawling bees were found among the hundreds of dead bees lying just behind the entrance of these hives. Inside the trap hives, trembling bees were observed on shallow frames and dead bees had accumulated on the bottom of the hives. Trembling bees were again observed 8 days later within the most populous colony (hive number 17). Massive mortalities were found outside and inside of all three trap hives until the removal of the pollen traps. After removing the traps, no trembling bees were observed and very few dead bees were found in front of the hives during the rest of the study. Varroa destructor on larvae and crippled bees were found in two trap colonies (hives 20 and 21 ) on day $23,29,35$, and 42.

During the study period, no trembling symptoms or massive mortalities were observed in either control hive (Table I). However, a few dead bees were found in front of one control hive (control hive 7 on day 23 and 29). This colony also showed larvae with saccules on day 29, 35, and 42. Clinical signs of varroosis (mites on brood or bees, and/or bees with deformed wings) were found in hive 59 on day 35 .

\subsection{Viral load in bee and larvae samples}

Figure 2 shows the average CBPV load in samples of dead bees, foragers, emerging bees, and larvae from control hives (Figure 2a) and from hives fitted with pollen traps (Figure 2b). The viral loads quantified in the emerging bees and the larvae collected in both hive groups were most frequently unquantifiable because the data were below the LOQ of the RTqPCR method (< $10^{3.9} \mathrm{CBPV} /$ individual). One sample of emerging bees (day 15) and one sample of sealed brood (day 29) were found with CBPV loads higher than the LOQ inside control hives. Inside trapped hives, one sample of emerging bees (day 29) and three samples of sealed brood (days 0, 23, and 29) were found with CBPV loads higher than the LOQ. All foragers and dead bees from the trap and control hives were infected by CBPV at the beginning of the study; their viral loads ranged from $10^{6}$ to up to $10^{10} \mathrm{CBPV} /$ bee. The viral loads (up to $10^{8} \mathrm{CBPV} / \mathrm{bee}$ ) quantified in the dead bees collected in front of both hive groups were not statistically different 
Table I. Clinical signs observed in control hives and hives fitted with pollen traps.

\begin{tabular}{|c|c|c|c|c|c|c|c|c|c|c|}
\hline \multirow[t]{3}{*}{ Days } & \multicolumn{4}{|c|}{ Control hives ${ }^{\mathrm{a}}$} & \multicolumn{6}{|c|}{ Trap hives $^{\mathrm{b}}$} \\
\hline & \multicolumn{2}{|l|}{59} & \multicolumn{2}{|l|}{7} & \multicolumn{2}{|l|}{17} & \multicolumn{2}{|l|}{20} & \multicolumn{2}{|l|}{21} \\
\hline & $\mathrm{CS}^{\mathrm{c}}$ & $M^{\mathrm{d}}$ & $\mathrm{CS}$ & M & $\mathrm{CS}$ & M & CS & M & $\mathrm{CS}$ & M \\
\hline 0 & No & 2 & No & 2 & No & 2 & No & 2 & No & 2 \\
\hline 15 & No & 2 & No & 2 & Yes & 3 & Yes & 3 & Yes & 3 \\
\hline 23 & No & 2 & No & 1 & Yes & 3 & Yes & 3 & Yes & 3 \\
\hline 29 & No & 2 & No & 1 & No & 3 & No & 2 & No & 2 \\
\hline 35 & No & 1 & No & 1 & No & 3 & No & 2 & No & 2 \\
\hline 42 & No & 1 & No & 1 & No & 2 & No & 2 & No & 2 \\
\hline
\end{tabular}

${ }^{\text {a }}$ Control hive group includes two hives without pollen traps (hive number 59 and 7)

${ }^{\mathrm{b}}$ Trap hive group includes three hives set with pollen traps (hive number 17, 20, and 21); the pollen traps were installed between day 0 and 23

${ }^{\mathrm{c}} \mathrm{CS}$ : Clinical signs of chronic bee paralysis observed (yes) or not observed (no)

${ }^{\mathrm{d}} \mathrm{M}$ : Mortality levels with 1 for $n<10$ dead bees; 2 for $10 \geq n \geq 100$ dead bees; 3 for $n>100$ dead bees

$(P=0.12)$. Only viral loads quantified in foragers from both treatments were statically different $(P<0.01)$. High viral loads were quantified in the foragers collected on the flight board of the trap hives for the period during which the pollen traps were in place. After trap removal, the viral load in the foragers decreased. The viral load in dead bees sampled during the study, in front of the trap hives or the control hives, reached up to $10^{8}$ CBPV/bee. During the first 23 days of the experiment, the viral load gradually decreased in the samples of foragers from the control colonies. A transient increase in the viral load was detected on day 29 in the bees sampled on the flight board of the control hives (viral load less than $10^{6} \mathrm{CBPV} /$ bee).

\section{DISCUSSION}

This limited study carried out during the spring 2014 , on five honeybee colonies naturally infected by CBPV strongly suggests that the use of pollen traps can induce a relapse in clinical signs of chronic bee paralysis and kept at high level the viral load of CBPV in foragers (up to $10^{10}$ CBPV/bee).
The colonies selected for the study had been naturally infected by CBPV and had shown clinical signs of chronic bee paralysis (trembling bees, black bees, crawling bees, and massive mortalities in front of the hives) 1 month prior to the beginning of the experiment. At the beginning of the study, the colonies were apparently healthy and few dead bees were found in front of each hive. However, the viral loads greater than $10^{8} \mathrm{CBPV} /$ bee indicate that CBPV infected all colonies, and especially the foragers sampled in the five colonies.

Fifteen days after the installation of the pollen traps, the clinical signs of the disease and excess mortalities were clearly observed in the three trap hives, whereas the two control hives remained healthy. The clinical signs of the disease may have occurred before day 15. Experimentally, we have previously shown that clinical signs of CBPV can be observed 5 days after inoculation of CBPV (Ribière et al. 2007; Youssef et al. 2015), but we did not expect clinical signs at the colony level before day 15. Therefore, future studies should plan for a first visit about 1 week after exposure to the risk factor of clinical disease.

During our study (and notably during the period of pollen trapping), the viral loads in the foragers from trap hives were higher than the viral loads in the foragers from the control colonies 

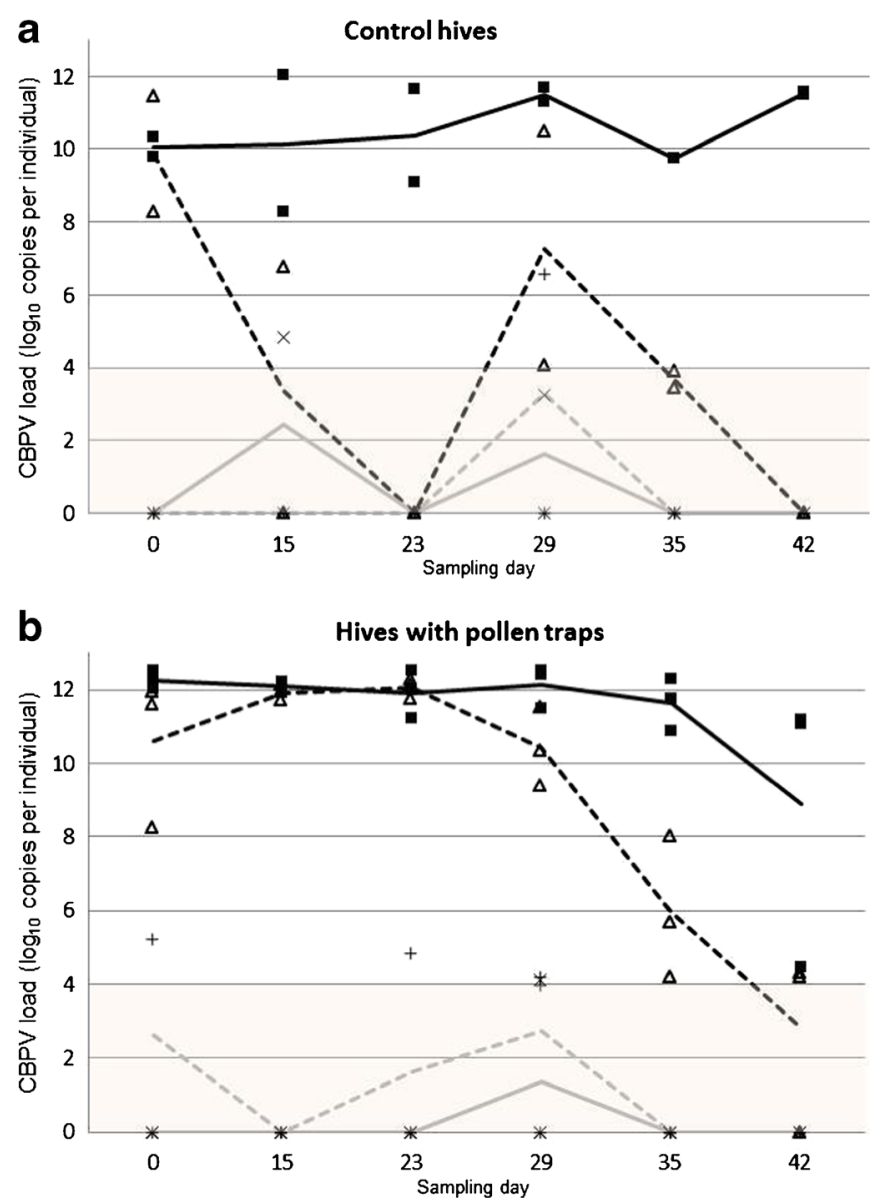

Figure 2. CBPV loads quantified in honeybee samples collected from two control hives (a) and three hives fitted with pollen traps (b). Dead bees (individual loads: $\mathbf{m}$; average load: black line) were collected outside the hives on the ground. The foragers (individual loads: $\Delta$; average load: black dashed line) were collected on the flight board. Emerging bees (individual loads: $\times$; average load: gray line) and sealed brood (individual loads: + ; average load: gray dashed line) were sampled inside the hives. The CBPV load was quantified in pool of ten individuals using RTqPCR. The results are expressed as $\log _{10}$ of CBPV RNA copies detected per individual. The pollen traps were installed between day 0 and 29. The shaded zone (between 0 and $4 \log _{10}$ CBPV per individual) indicates the limit of quantification of the method (with an uncertainty over $0.5 \log _{10} \mathrm{CBPV}$ per individual).

$(P<0.01)$. The viral loads quantified in the dead bees from control and trap hives were greater than $10^{8} \mathrm{CBPV} /$ bee in both groups. As previously reported (Blanchard et al. 2007), viral loads in emerging bees or sealed brood remained lower than in adult bees in both control and trap hives. Despite the non-parametric test indicates significant differences in viral loads between foragers from both treatments, definite conclusions may require studies involving a larger number of colonies. The effect of pollen traps on mortality was clearly observed in the number of dead bees.
Although the dead bees were sometimes blown off the plastic tarp by the wind (and/or predated by ants), the number of dead bees found in front of the trap hives was clearly higher than the number of dead bees found in front of control hives. Precision in the dead bee count can be improved by placing a collecting device at the entrance of the hive (Pérez et al. 2001).

The transmission of CBPV by contact can be experimentally reproduced by infecting honeybees with CBPV-infected feces or with a viral suspension spotted on shaved (hairless) cuticles 
(Ribière et al. 2010). The screens of the pollen traps may favor the occurrence of the clinical paralysis in two ways. First, the screens themselves may be infected by CBPV-infected foragers and subsequently transmit the virus horizontally by abrasion of the cuticle of healthy bees. Second, the screens impede the expulsion of the dead bees that accumulate inside the hive, which may promote colony contamination. The confinement of infected bees inside the hive may explain also the clinical cases of chronic bee paralysis observed in populous colonies after a few days of rain; increased contact between bees that remain confined in the hive consequently increases the number of infected bees (Ribière et al. 2010).

Honeybees and especially the guards try to expulse the symptomatic bees from the colony that fall on the floor at the hive entrance where they die (Ribière et al. 2010). However, CBPV can be spread to neighboring colonies by drifting of infected foragers. Drifting likely occurred during this study on day 29. CBPV-infected bees detected on the flight board of control hives may have been foragers rejected from the trap hives that were only $10 \mathrm{~m}$ away. Although CBPV infects the central cortex of honeybees (Olivier et al. 2008) at the first stage of the disease, the foragers can fly back to the colony or, rejected by the guards from their own colony, may nevertheless be able to fly to neighboring colonies. The guards in contact with infected bees are thus exposed to CBPV (Blanchard et al. 2007), increasing the risk of virus spread to the entire colony. Hence, an apiary with colonies close together could be considered, for this disease, as an epidemiological unit in which the virus can be transmitted from one colony to another by drifting of the honeybees. Recommendations provided to reduce drifting (i.e., distance between hives, orientation of the hive entrances; Pfeiffer and Crailsheim 1998) may reduce the expansion of the chronic bee paralysis in apiaries.

During this study, the clinical signs of chronic bee paralysis did not induce the losses of the trap colonies. The mortalities observed outside and inside the hives during this study, as well as the clinical signs previously described for the chronic bee paralysis, cannot be confused with cases of colony collapse disorder (CCD) because in $\mathrm{CCD}$, there are no dead bees (Cox-Foster et al. 2007; Stokstad 2007). Other viruses such as acute bee paralysis virus or related viruses (Kashmir bee virus and Israeli acute paralysis virus) and deformed wing virus (DWV) are pathogens that are potentially associated with CCD (Chejanovsky et al. 2014; Cox-Foster et al. 2007; Dainat et al. 2012). Co-exposure of the honeybees to several stressors (biotic or abiotic) can impair colony health (Goulson et al. 2015). This study suggests that colony strength may be reduced by chronic bee paralysis (and pollen deficiency associated with the prolonged use of pollen traps), making it more sensitive to intercurrent pathogens. The colonies of the control hives seemed to be less sensitive to Varroa destructor and/or other viral infections (crippled bees and larvae with saccules being associated with DWV or sacbrood virus infections, respectively). Despite the detection of clinical signs of other bee diseases, the control colonies seemed stronger at the end of the study than the colonies from the trap hives, even hive 17 which was the strongest colony at the beginning of the study. The use of robust methods to assess the level of mite infestation and to evaluate the honey bee activity over time would describe with a better accuracy the strength of the colonies (Dietemann et al. 2013; Maisonnasse et al. 2016). Moreover, the assessment of effects of supplementary stressors on the susceptibility of honeybees to CBPV would require larger sample sizes. The difficulties would be to find enough colonies infected by CBPV to be included in next studies.

Each year, our laboratory collects pollen for its own purposes. The year after this study, we did not observe clinical signs of chronic bee paralysis in the foragers from eight trap hives (data not shown). The foragers of each trap hives, sampled the day of installation of pollen traps and 14 days later, were negative for CBPV by RT-qPCR (data not shown). Therefore, clinical cases of chronic bee paralysis are not systematically associated with the use of pollen traps. CBPV is the etiological agent of a contagious disease. Without infectious virus particles to contaminate the pollen trap or enough infected bees contaminating the pollen traps and /or dying inside the colony, the disease does not occur. 
A recent study shows that teaching good beekeeping practices to beekeepers and identifying diseases is an important factor in good colony health (Jacques et al. 2017). Therefore, we recommend collecting pollen only from apparently healthy colonies (never after a recent case of chronic bee paralysis) and installing pollen traps for only a short period of time, removing them as soon as clinical signs are observed and particularly when dead bees are accumulating outside or inside the hive. In addition, pollen traps must be thoroughly cleaned and disinfected before use. Pollen traps could promote other diseases transmitted by contact. Therefore, these recommendations could favor the overall health of the colony.

\section{ACKNOWLEDGEMENTS}

We are grateful to Carolyn Engel-Gautier, professional translator and native English speaker, for revising the paper.

\section{AUTHOR CONTRIBUTIONS}

$\mathrm{ED}, \mathrm{FS}, \mathrm{NC}$, and MRC participated in the design and interpretation of the data; CR, FS, NC, and ED performed experiments; ED and MRC wrote the paper. All authors read and approved the final manuscript.

Effet des pièges à pollen sur la réapparition du virus de la paralysie chronique dans les colonies de l'abeille (Apis mellifera)

Perte de colonies / affaiblissement / butineuse / maladie à virus

Einfluß von Pollenfallen auf das Wiederauftreten des Chronischen Bienenparalyse-Virus in Honigbienenvölkern (Apis mellifera)

Völkerverluste / Schwächung / Sammelbienen / Viruserkrankungen

\section{REFERENCES}

Allen, M., Ball, B. (1996). The incidence and world distribution of honey bee viruses. Bee World 77 (3), 141162
Bailey, L., Gibbs, A. J., Woods, R. D. (1963). Two viruses from adult honey bees (Apis mellifera Linnaeus). Virology 21 (3), 390-395

Ball, B.V., Bailey, L. (1997) Viruses in Morse, R.A. and Flottum, K. (Eds), Honey bee pests, predators, and diseases. The A.I. Root Company, pp.11-32

Blanchard, P., Ribière, M., Celle, O., Lallemand, P., Schurr, F., Olivier, V., Iscache, A.L., Faucon, J. P. (2007). Evaluation of a real-time two-step RT-PCR assay for quantitation of Chronic bee paralysis virus (CBPV) genome in experimentally-infected bee tissues and in life stages of a symptomatic colony. J. Virol. Methods 141 (1), 7-13

Blanchard, P., Schurr, F., Olivier, V., Celle, O., Antunez, K., et al. (2009). Phylogenetic analysis of the RNAdependent RNA polymerase (RdRp) and a predicted structural protein (pSP) of the Chronic bee paralysis virus (CBPV) isolated from various geographic regions. Virus Res. 144 (1-2), 334-338

Blanchard, P., Regnault, J., Schurr, F., Dubois, E., \& Ribiere, M. (2012). Intra-laboratory validation of chronic bee paralysis virus quantitation using an accredited standardised real-time quantitative RTPCR method. J. Virol. Methods 180 (1-2), 26-31

Chauzat, M. P., Jacques, A., EPILOBEE consortium, Laurent, M., Bougeard, S., Hendrikx, P., RibièreChabert, M. (2016). Risk indicators affecting honeybee colony survival in Europe: one year of surveillance. Apidologie 47 (3), 348-378

Chejanovsky, N., Ophir, R., Schwager, M. S., Slabezki, Y., Grossman, S., Cox-Foster, D. (2014). Characterization of viral siRNA populations in honey bee colony collapse disorder. Virology, 454-455, 176-183

Cox-Foster, D. L., Conlan, S., Holmes, E. C., Palacios, G., Evans, J. D., et al. (2007). A metagenomic survey of microbes in honey bee colony collapse disorder. Science 318 (5848), 283-287

Dainat, B., Evans, J. D., Chen, Y. P., Gauthier, L., Neumann, P. (2012). Predictive markers of honey bee colony collapse. PLoS One 7 (2), e32151. https://doi. org/10.1371/journal.pone.0032151

De Miranda, J. R., Bailey, L., Ball, B. V., Blanchard, P., Budge, G. E., et al. (2013). Standard methods for virus research in Apis mellifera. J. Apic. Res., 52 (4). https://doi.org/10.3896/IBRA.1.52.4.22

Denisow, B., Denisow-Pietrzyk, M. (2016). Biological and therapeutic properties of bee pollen. A review. J. Sci. Food Agric., https://doi.org/10.1002/jsfa.7729

Di Pasquale, G., Salignon, M., Le Conte, Y., Belzunces, L. P., Decourtye, A., Kretzschmar, A., Suchail, S., Brunet, J.L., Alaux, C. (2013). Influence of pollen nutrition on honey bee health: do pollen quality and diversity matter? PLoS One 8(8), e 72016. https://doi.org/10.1371 /journal.pone.0072016

Dietemann, V., Nazzi, F., Martin, S. J., Anderson, D. L., Locke, B., Delaplane, K. S., Wauquiez, Q., Tannahill, C., Frey, E., Ziegelmann, B., Rosenkranz, P., Ellis, J. D. (2013). Standard methods for varroa research. J. Apic. Res. 52(1). https://doi.org/10.3896 /IBRA.1.52.1.09 
Goulson, D., Nicholls, E., Botías, C., Rotheray, E.L. (2015). Bee declines driven by combined stress from parasites, pesticides, and lack of flowers. Science $\mathbf{3 4 7}$, 1255957. https://doi.org/10.1126/science. 1255957

ITSAP (2014). La maladie noire (paralysie chronique de l'abeille, mal des forêts, petites noires, Chronic bee paralysis virus, $\mathrm{CBPV}$ ) in Guide des bonnes pratiques apicoles, ITSAP-Institut de 1'abeille (itsap@itsap.asso.fr), Paris, pp. M6

Jacques, A., Laurent, M., Ribière-Chabert, M., Saussac, M., Bougeard, S., Budge, G. E., Hendrikx, P., Chauzat, M. P. (2017). A pan-European epidemiological study reveals honey bee colony survival depends on beekeeper education and disease control. PLoS One 12 (3), e0172591. https://doi.org/10.1371/journal. pone. 0172591

Maisonnasse, A., Hernandez, J., Le Quintrec, C., Cousin, M., Beri, C., Kretzschmar, A. (2016). Evaluation de la structure des colonies d'abeilles, création et utilisation de la méthode ColEval (Colony Evaluation). Innov. Agronomiques 53, 27-37

Olivier, V., Massou, I., Celle, O., Blanchard, P., Schurr, F., Ribière, M., Gauthier, M. (2008). In situ hybridization assays for localization of the chronic bee paralysis virus in the honey bee (Apis mellifera) brain. J. Virol. Methods 153 (2), 232-237

Pérez, J. L., Higes, M., Suárez, M., Llorente, J., Meana, A. (2001). Easy ways to determine honey bee mortality using dead-bee traps. J. Apic. Res. 40 (1), 25-28
Pfeiffer, K.J., Crailsheim K. (1998). Drifting of honeybees. Insect. Soc. 45, 151-167

Potts, S. G., Roberts, S. P. M., Dean, R., Marris, G., Brown, M. A., Jones, R., Neumann, P., Settele, J. (2010). Declines of managed honey bees and beekeepers in Europe. J. Apic. Res. 49(1), 15-22

Ribière, M., Lallemand, P., Iscache, A. L., Schurr, F., Celle, O., Blanchard, P., Olivier, V., Faucon, J. P. (2007). Spread of infectious chronic bee paralysis virus by honeybee (Apis mellifera L.) feces. Appl. Environ. Microbiol. 73 (23), 7711-7716

Ribière, M., Olivier, V., Blanchard, P. (2010). Chronic bee paralysis: a disease and a virus like no other? J. Invertebr. Pathol., 103 Suppl 1, S120-131

Scofield, H. N., Mattila, H. R. (2015). Honey bee workers that are pollen stressed as larvae become poor foragers and waggle dancers as adults. PLoS One, $10(4)$, e0121731. https://doi.org/10.1371/journal. pone. 0121731

Stokstad, E. (2007). Entomology. The case of the empty hives. Science, $\mathbf{3 1 6}$ (5827), 970-972

Youssef, I., Schurr, F., Goulet, A., Cougoule, N., RibièreChabert, M., Darbon, H., Thiéry, R., Dubois, E. (2015). RNA 1 and RNA 2 Genomic Segments of Chronic Bee Paralysis Virus Are Infectious and Induce Chronic Bee Paralysis Disease. J Immunol Res, https://doi.org/10.1155/2015/423493 